\title{
Partial characterisation of alkaline phosphatase in Fasciolopsis buski - an intestinal fluke treated with crude extract of Alpinia nigra (Zingiberaceae)
}

\author{
Ananta Swargiary, Bishnupada Roy* and Bhabesh Ronghang \\ ${ }^{*}$ Correspondence: bishnuroy12@rediffmail.com \\ Department of Zoology, North-Eastern Hill University, Shillong - 793022, India.
}

\begin{abstract}
Background: Alkaline phosphatase is an important enzyme of helminth parasites that are found to be associated with absorption and/or digestion of food materials. Any interference to this enzyme could lead to paralysis and death of the parasites. In view of its functional significance, the present study was carried out to partially characterise the alkaline phosphatase of a fluke parasite, Fasciolopsis buski and to study the inhibitory effect of the extracts of Alpinia nigra, a medicinal plant of north-east India.

Methods: Edible fresh shoots of Alpinia nigra were collected from Tripura, India and crude extract was extracted in ethanol. Live and mature F. buski was collected from the intestine of freshly slaughtered pig from the local abattoir and brought to the laboratory and processed for study. Various biochemical parameters like effect of $\mathrm{pH}$, temperature, incubation, kinetic parameters and effects of $A$. nigra extract were studied on the alkaline phosphatase activity. A commercial anthelmintic drug praziquantel was taken as reference drug.

Results: The optimal $\mathrm{pH}$ and temperature of the enzyme ranged between 9.0 to 10.0 and $35^{\circ} \mathrm{C}$ to $45^{\circ} \mathrm{C}$, respectively. Alkaline phosphatase activity exhibited linear Arrhenius relationship with corresponding catalytic energy of activation (Ea) of $10.1 \mathrm{Kcal} \mathrm{mole}^{-1}$. The $\mathrm{Km}$ and Vmax values were $2.5 \mathrm{mM}$ and $16.67 \mu \mathrm{M} / \mathrm{min}$, respectively. The plant extract and the drug inhibited the enzyme activity in a dose-dependent manner with IC50 values of $1.10 \mathrm{mg} / \mathrm{ml}$ and $25 \mu \mathrm{M} / \mathrm{ml}$ for the plant extract and praziquantel, respectively. The kinetic parameters ( $\mathrm{Km}$ and Vmax) were found to be altered both in the plant extract and drug treated parasite. Therefore, the alteration of the kinetic parameters by the crude extract of A. nigra and praziquantel treatment indicates a mixed type of alkaline phosphatase enzyme inhibition in F. buski.

Conclusion: The altered enzyme activities, as observed under influence of the plant extract clearly indicate that the active principle of the plant acts as anthelminthic. However, to exploit the plant for commercial purpose, it is prerequisite to isolate and identify the active component responsible for anthelmintic activity.
\end{abstract}

Keywords: Alkaline phosphatase, Fasciolopsis buski, Alpinia nigra, praziquantel, Michaelis-Menten

\section{Background}

Alkaline phosphatase (AlkPase) is the enzyme that catalyses the hydrolysis of various phosphate esters and exhibit maximum activity in alkaline $\mathrm{pH}$. The enzyme is found in the cells and extracellular fluids of a wide range of organisms including helminth parasites. Histochemical and biochemical studies have confirmed the presence of AlkPase in close associations with tegument, sub-tegument, somatic musculature, gut and cuticle of various helminth parasites, particularly in the adhesive organs like acetabulum and oral suckers [1-5]. Tegument is the outermost body covering of cestode and trematode parasites through which absorption and/or digestion of various food materials takes place [6-7]. Literatures have also shown that higher concentrations of AlkPase are found in the areas of intestine and sub-cuticular layers of the worm associated with proteins transport [8]. Thus, any interference or inhibition to this enzyme could lead to alteration of body physiology in helminth parasites.

Various commercial drugs (anthelmintic) and chemical compounds revealed to bring about changes in the activities of AlkPase in various soft-bodied helminth parasites like Echinococcus multilocularis, Raillietina echinobothrida, Hymenolepis diminuta, Schistosoma mansoni, Fasciolopsis buski and Fasciola hepatica [9-12]. In our earlier studies, in vitro exposure of $F$. buski to the alcoholic crude extract of $A$. nigra revealed alteration in the activities of different tegumental enzymes [13]. However, no literature is available on the altered kinetics of AlkPase in trematode parasites treated with anthelmintic phytochemicals. Therefore, in view of the functional significance, the present study was designed to characterise AlkPase in F. buski and analyse the in vitro effect of crude extract of Alpinia nigra on the activity of the enzyme.

\section{Materials and Methods}

Plant extract and test parasite

Collection of plant material and preparation of crude extract was carried out as described earlier [13]. Briefly, fresh edible shoots of Alpinia nigra were collected from

C 2013 Roy et al; licensee Herbert Publications Ltd. This is an Open Access article distributed under the terms of Creative Commons Attribution License (http://creativecommons.org/licenses/by/3.0). This permits unrestricted use, distribution, and reproduction in any medium, provided the original work is properly cited. 


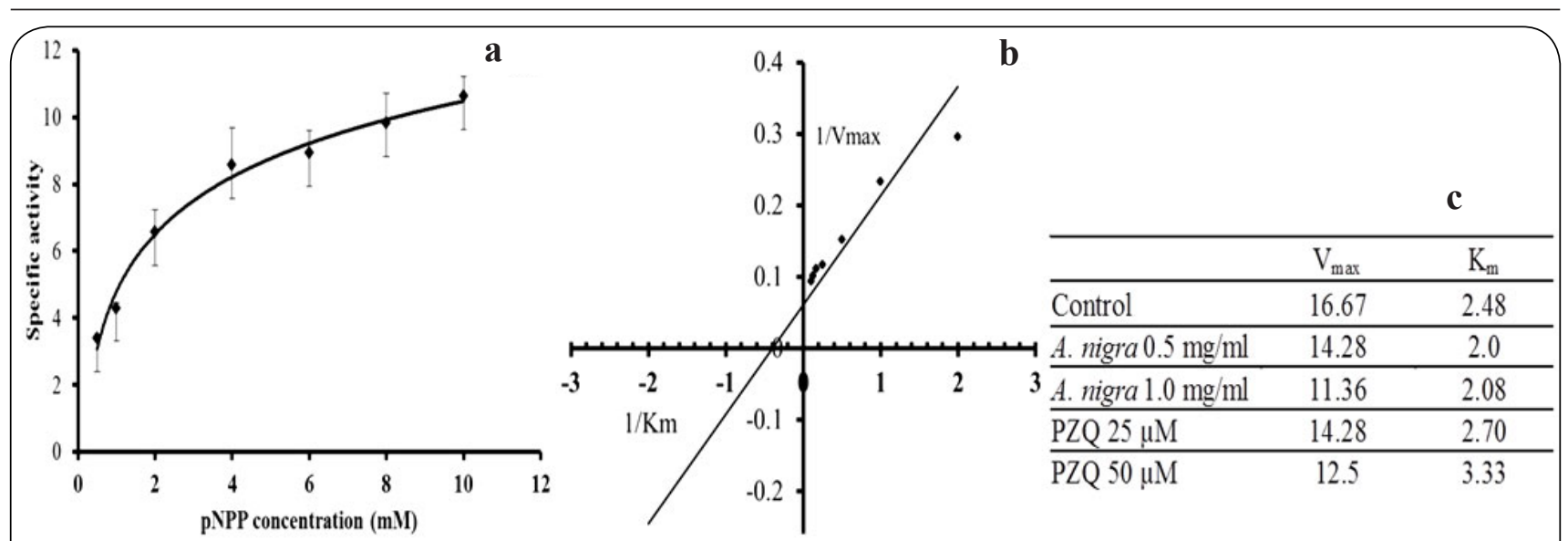

Figure 1. Graphical representation of the (a) effect of substrate, (b) Lineweaver-Burk plot and (c) kinetic parameters $\mathrm{K}_{\mathrm{m}}$ and Vmax of alkaline phosphatase of untreated control tissue of F. buski.

Tripura, India. After washing gently with distilled water, the shoots were air-dried, grounded by motor-driven grinder, soaked in $90 \%$ ethanol for 3 to 4 days and refluxed in the same solvent for 12 hours at $60^{\circ} \mathrm{C}$. After reflux, the solution obtained was filtered through Whatman filter paper No. 1 and the solvent of the filtrate was evaporated at $50^{\circ} \mathrm{C}$ to recover dry powder. Recovered powder was stored at $4^{\circ} \mathrm{C}$ till further use. Live and mature Fasciolopsis buski were collected in $0.9 \%$ phosphate buffered saline ( $\mathrm{pH} 7.4)$ from the intestine of freshly slaughtered pig from the local abattoir and brought to the laboratory and processed for study. A commercial drug, praziquantel (PZQ) has been used as a reference drug.

\section{Quantification and characterisation of alkaline phosphatase}

A $10 \%$ tissue homogenate was made in ice cold $100 \mathrm{mM}$ sodium-glycine buffer ( $\mathrm{pH}$ 9.5). The homogenate was centrifuged at $6,000 \mathrm{rpm}$ for $30 \mathrm{~min}$ at $4^{\circ} \mathrm{C}$. Crude tissue supernatant obtained was used for enzyme studies. AlkPase activity was assayed following the method of Plummer [14]. The assay mixture consisted of $80 \mathrm{mM}$ glycine- $\mathrm{NaOH}$ buffer ( $\mathrm{pH}$ range 8-11), $1 \mathrm{mM} \mathrm{MgCl} 2^{\prime} 2.5 \mathrm{mM} \mathrm{p-nitrophenyl}$ phosphate ( $p N P P), 0.05 \mathrm{ml}$ of tissue supernatant (tissue protein $=0.10 \mathrm{mg} / \mathrm{ml}$ ) and incubated for $30 \mathrm{~min}$ at $37 \pm 1^{\circ} \mathrm{C}$. The reaction was stopped by adding $2 \mathrm{ml}$ of $0.2 \mathrm{~N} \mathrm{NaOH}$ at the end of incubation and absorbance measured at $410 \mathrm{~nm}$ in a double beam spectrophotometer (Carry 100, Varian). Influence of $\mathrm{pH}$ in the enzyme activities was studied by taking the $\mathrm{pH}$ range of $8.0-11.0$. The effect of incubation time and temperature was analysed within a range of 1 to $60 \mathrm{~min}$ and $5^{\circ} \mathrm{C}$ to $70^{\circ} \mathrm{C}$, respectively. The activation energy of enzyme in relation to changes in temperature and rate of reaction has been calculated by Arrhenius equation following Njoku et al., [15] as follows:

$\ln (k)=\ln (A)-E a / R T$, Slope $=-E a / R$ and therefore, $E a=$ Slope $\times \mathrm{R}$;

Where, $\mathrm{k}=$ Rate constant (enzyme activities), $\mathrm{A}=$ Pre- exponential factor, Ea $=$ Activation energy, $\mathrm{R}=\mathrm{Gas}$ constant (1.98 cal kelvin ${ }^{-1} \mathrm{~mol}^{-1}$ ) and $\mathrm{T}=$ Absolute temperature in kelvin.

The effect of crude extract of $A$. nigra and commercial drug praziquantel was determined by taking the concentration ranged from 0.1 to $5.0 \mathrm{mg} / \mathrm{ml}$ for the plant extract and $5-200 \mu \mathrm{M} / \mathrm{ml}$ for the reference drug PZQ, respectively. To determine the kinetic parameters $\left(\mathrm{K}_{\mathrm{m}}\right.$ and $\left.\mathrm{V}_{\text {max }}\right)$, a nonlinear regression was employed at optimum $\mathrm{pH} 9.5$ and temperature $37 \pm 1^{\circ} \mathrm{C}$, with substrate concentrations between 0.1 and $20 \mathrm{mM}$. The concentrations of the plant extract and the drug that inhibited $50 \%$ of enzyme activity $\left(\mathrm{IC}_{50}\right)$ was estimated following Kamal et al., [16] and Alhomida et al., [17]. The graphs were drawn by plotting $\%$ activity and $\%$ inhibition of alkaline phosphatase versus extracts of $A$. nigra $(0.1-5.0 \mathrm{mg} / \mathrm{ml})$ and PZQ $(5-200 \mu \mathrm{M})$. The concentrations at the intersections of these two curves were taken as the $\mathrm{IC}_{50}$ values. All the results are expressed as units/mg tissue protein [1 unit $(\mathrm{U})=1 \mu \mathrm{M} p$-nitrophenol $\mathrm{min}^{-1} \mathrm{mg}$ protein ${ }^{-1}$.

\section{Tissue protein and statistical calculation}

The protein content of $F$. buski was measured following the standard method of Lowry et al., [18] using BSA ( $250 \mu \mathrm{g} /$ $\mathrm{ml}$ ) as a standard protein. All experiments were carried out for four replicates $(n=4)$. All the calculations were carried out at Microsoft Excel and Origin software. Results were represented as the \pm SEM (standard error of means). The probability analysis was done using Origin Pro8 software at $0.05 \%$ significance level.

\section{Results and Discussion}

The result indicates a good relationship between the AlkPase activity and the $p$-nitrophenyl phosphate ( $p$ NPP, the substrate) concentration. Increasing the substrate concentration from 0.5 to $10 \mathrm{mM}$, a linear increase in the enzyme activities (represented as units) in accordance with the normal pattern of enzymatic reactions has been observed (Figure 1a). Higher enzyme activity (velocity, V) has 

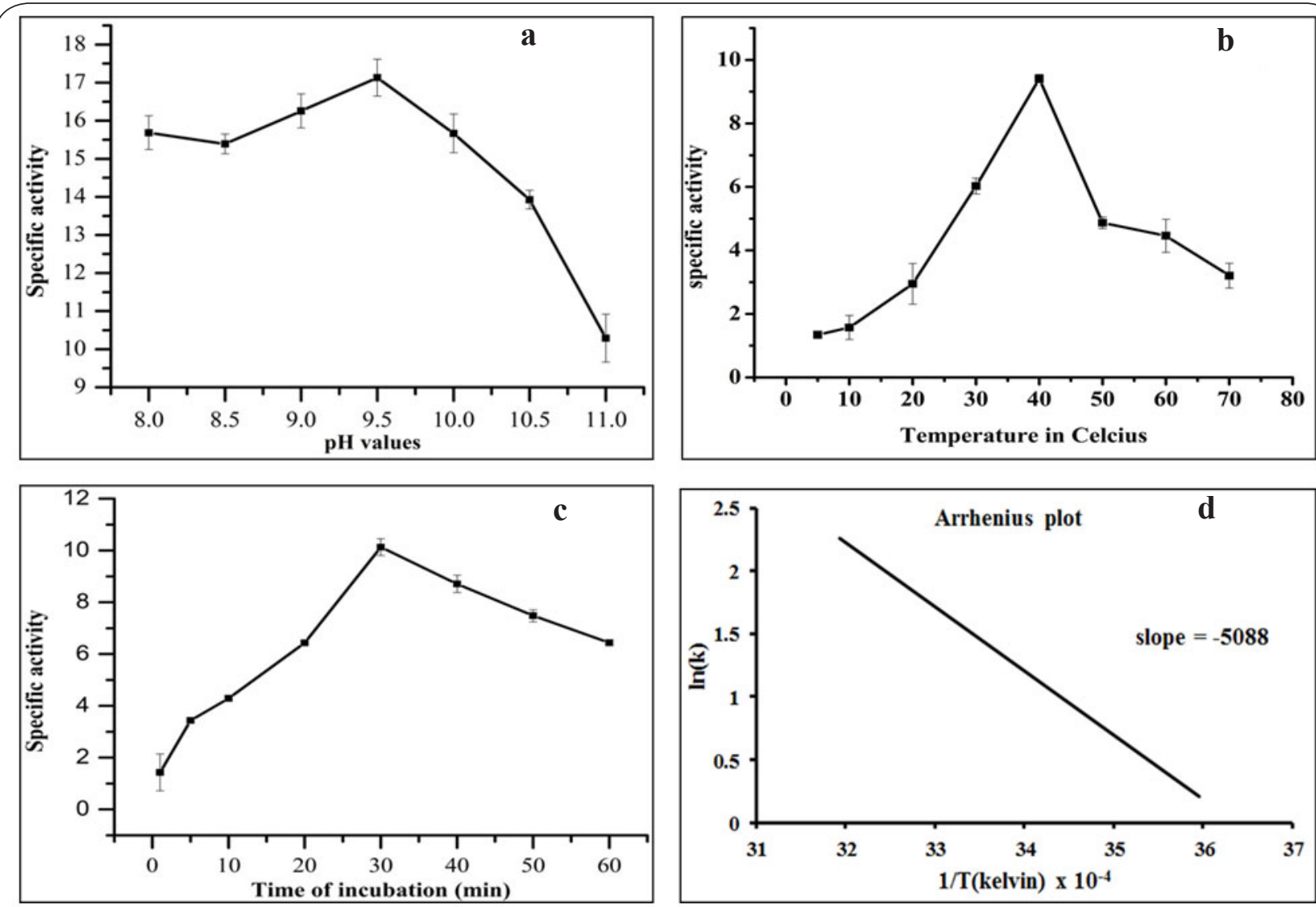

Figure 2. Influence of (a) $\mathrm{pH}$, (b) temperature and (c) incubation time on the enzyme activities and (d) Arrhenius plot showing the relation between temperature and enzyme activity.

been observed in lower substrate concentrations ranging 0.5 to $4 \mathrm{mM}$ and thereafter, not much change has been observed, indicating the attainment of maximum velocity of the enzyme activity. When the data were plotted in a Lineweaver-Burk plot, the $\mathrm{K}_{\mathrm{m}}$ and $\mathrm{V}_{\max }$ were found to be 2.48 $\mathrm{mM}$ and $16.67 \mathrm{U}$, respectively (Figure $1 \mathbf{b}, \mathrm{c}$ ). Lawton et al. , [19] studied the kinetic parameters of alkaline phosphatase in the membrane of hydatid cyst of Echinococcus granulosus and observed $\mathrm{K}_{\mathrm{m}}$ and $\mathrm{V}_{\max }$ values $0.24 \pm 0.05 \mathrm{mM} / \mathrm{L}$ and $173 \pm 21 \mathrm{nM} / \mathrm{min} / \mathrm{mg}$ proteins for $p$-nitrophenylphosphate, respectively. Almost a similar kind of kinetic parameters has also been observed in other organism like Scrobicularia plana, where the enzyme attained half-maximum velocity at substrate concentration of $2.48 \mathrm{mM}$ [20]. Whereas, in rabbit liver, a maximum activity of AlkPase (20 Umin $\left.{ }^{-1}\right)$ was observed at $p$ NPP concentration of $0.5 \mathrm{mM}$ [15].

The influences of $\mathrm{pH}$, temperature and the incubation time on the AlkPase activity is depicted in figure 2. The affinity of an enzyme to bind to a specific substrate depends on the ionization states of the amino acid residues in the catalytic sites which are controlled by both the $\mathrm{pH}$ and the temperature. Variations of these factors modify the effective working efficiency of the enzymes by modifying the shape of the enzyme or denaturing its structure [21].
Increasing $\mathrm{pH}$ values has been found to have negative effect on the enzyme activities with lowest activity at $\mathrm{pH} 11.0$. The enzyme activities have also been seen to be greatly controlled by temperature fluctuations. Highest activity of AlkPase at $9.41 \pm 0.13 \mathrm{U}$ was found to be at temperature range of $35^{\circ} \mathrm{C}$ to $45^{\circ} \mathrm{C}$ (Figure 2 b) and decreased sharply with the increase of temperature above $40^{\circ} \mathrm{C}$. The Arrhenius plot (Figure $\mathbf{2 d}$ ) of temperature-dependent enzyme activities revealed activation energy (Ea) of $10.1 \mathrm{Kcal} \mathrm{mol}^{-1}$.

Activity of AlkPase increased with increasing incubation time up to $30 \mathrm{~min}$ and then decreased with the increase of incubation time (Figure 2). Probably, enzyme attains its maximum velocity within 30 min of incubation and then maintains the same speed and thereby less enzyme activity (units/mg protein) with the increase of incubation time. Effects of $\mathrm{pH}$, various chemicals and anthelmintics on the AlkPase activities of Ascaridia galli, Centrorhynchus convi, Raillietina cesticillus and Cotylophoron cotylophorum has also been studied by Parshad and Guraya [22] and showed that the optimum $\mathrm{pH}$ for maximum activity of the enzyme are 9.1, 9.5, 8.7 and 8.4, respectively. In a similar kind of experiment Morales et al., [23] purified the AlkPase from common bean (Phaseolus vulgaris L.) roots and studied various kinetic parameters. In their experiment optimum 


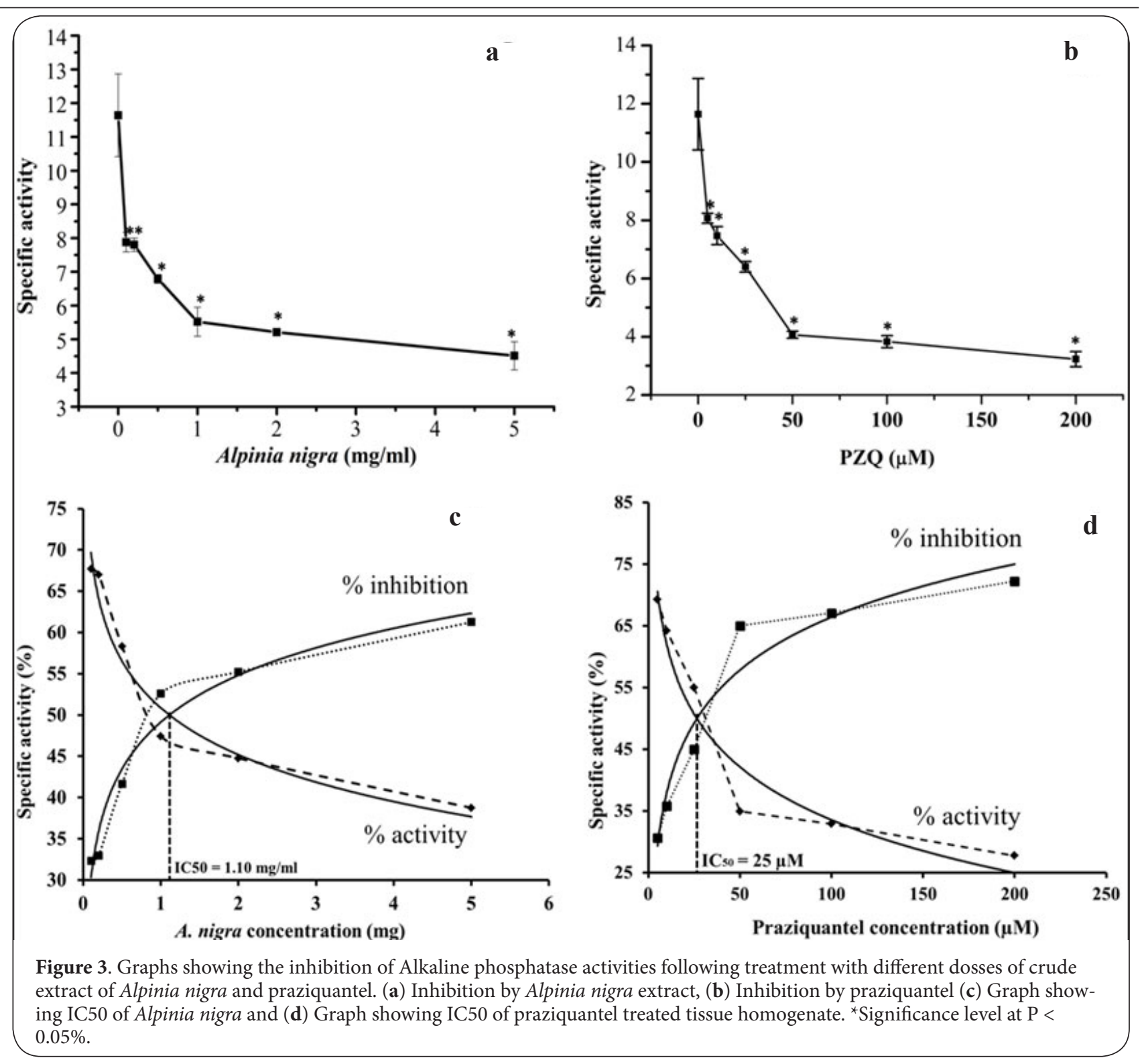

$\mathrm{pH}$ and temperature for the enzyme assay was found to be within $\mathrm{pH} 8$ and temperature of $37^{\circ} \mathrm{C}$, respectively. Similarly, the best $\mathrm{pH}$ range and incubation temperature was found to be $8.5-10.0$ and $30^{\circ} \mathrm{C}-40^{\circ} \mathrm{C}$ in crude tissue supernatant of Scrobicularia plana [20].

A significant $(p<0.05)$ difference in AlkPase activity has been observed between the control (11.64 $\pm 1.22 \mathrm{U}$ ) and the extract of $A$. nigra treated tissue homogenate and also between control and drug (PZQ) treated homogenate (Figure 3). Lowest enzyme activities $(4.51 \pm 0.42 \mathrm{U}$ and 3.23 $\pm 0.26 \mathrm{U}$ ) were observed when treated with highest doses of A. nigra $\left(5 \mathrm{mg} \mathrm{ml}^{-1}\right)$ and PZQ $\left(200 \mu \mathrm{M} \mathrm{ml}^{-1}\right)$, leading to almost $61 \%$ and $72 \%$ inhibition of enzyme activities, respectively (Figures 3a,3b). Two intersections between the $\%$ activity and $\%$ inhibition were taken as the $A$. nigra/drug concentrations where the enzyme activity showed $50 \%$ of reduction $\left(I_{50}\right)$. For both the A. nigra and PZQ, the $\mathrm{IC}_{50}$ were found to be
$1.10 \mathrm{mg}$ and $25 \mu \mathrm{M}$ respectively (Figures $3 \mathrm{c}, 3 \mathrm{~d}$ ).

Table 1 shows the comparative values of AlkPase activities of control and treated tissue. Significant difference (*labelled) of enzyme activities were observed in almost all the tissues treated with different concentrations of plant extract and commercial drug PZQ. At $0.5 \mathrm{mM}$ pNPP concentration no such significant differences in the enzyme activities were noticed in both the doses of $A$. nigra treated supernatant, compared to control ones. Enzyme activities of both treated and control vs. pNPP concentrations (Figure 4a) showed hyperbolic curves, suggesting little interference with the substrate concentration. The enzyme activities when plotted in a Lineweaver-Burk plot, the kinetic parameters $\mathrm{K}_{\mathrm{m}}$ and $\mathrm{V}_{\max }$ showed little modifications (Figure $4 \mathrm{~b}$ ). Control tissue showed $\mathrm{K}_{\mathrm{m}}$ and $\mathrm{V}_{\max }$ values of $4.48 \mathrm{mM}$ and $16.67 \mathrm{U}$; while the $A$. nigra treated tissue have $2.0 \mathrm{mM}$ and $14.28 \mathrm{U}$ for $0.5 \mathrm{mg} \mathrm{ml}^{-1}$ and 
Table 1. Comparative AlkPase activities in control and Alpinia nigra and Praziquantel treated Fasciolopsis buski tissue.

\begin{tabular}{llllll}
\hline $\boldsymbol{p N P P}(\mathbf{m M})$ & Control & Alpinia nigra 0.5 mg & Alpinia nigra 1.0 mg & Praziquantel 25 $\boldsymbol{\mu M}$ & Praziquantel 50 $\boldsymbol{\mu M}$ \\
\hline 5 & $3.74 \pm 0.04$ & $3.11 \pm 0.08$ & $2.89 \pm 0.03$ & $2.31 \pm 0.18^{*}$ & $1.91 \pm 0.12^{*}$ \\
1 & $4.3 \pm 0.15$ & $4.34 \pm 0.09$ & $3.45 \pm 0.15^{*}$ & $3.49 \pm 0.13^{*}$ & $3.09 \pm 0.10^{*}$ \\
2 & $6.57 \pm 0.66$ & $5.64 \pm 0.12^{*}$ & $5.09 \pm 0.20^{*}$ & $5.35 \pm 0.26^{*}$ & $4.75 \pm 0.23^{*}$ \\
4 & $8.56 \pm 1.11$ & $6.37 \pm 0.21$ & $6.08 \pm 0.21^{*}$ & $6.82 \pm 0.13^{*}$ & $5.80 \pm 0.06^{*}$ \\
6 & $8.94 \pm 0.66$ & $7.47 \pm 0.28^{*}$ & $6.70 \pm 0.21^{*}$ & $7.25 \pm 0.16^{*}$ & $6.39 \pm 0.24^{*}$ \\
8 & $9.83 \pm 0.87$ & $7.75 \pm 0.17^{*}$ & $6.79 \pm 0.21^{*}$ & $7.36 \pm 0.20^{*}$ & $6.88 \pm 0.13^{*}$ \\
10 & $10.65 \pm 0.56$ & $8.84 \pm 0.29^{*}$ & $7.98 \pm 0.26^{*}$ & $7.49 \pm 0.10^{*}$ & $6.24 \pm 0.15^{*}$ \\
\hline
\end{tabular}

*Significance level at $\mathrm{P}<0.05 \%$.
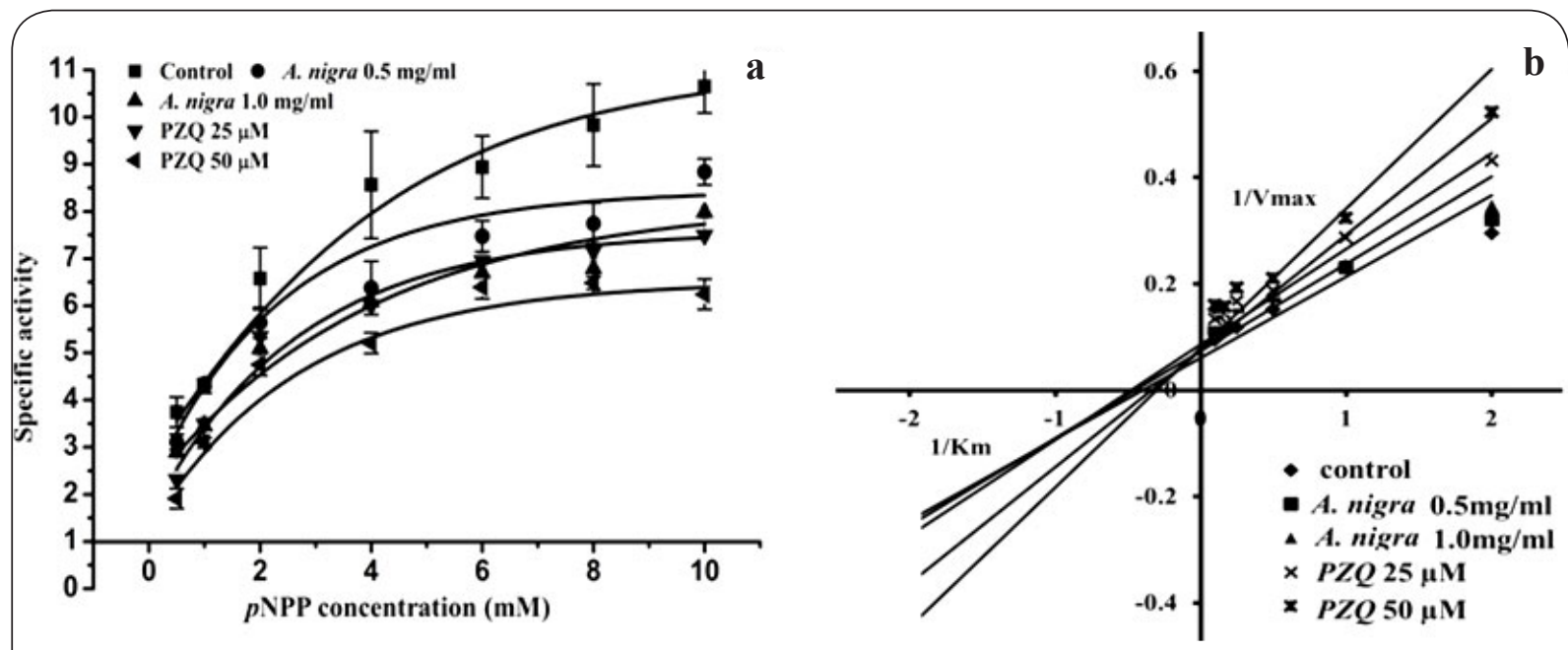

Figure 4. Graphical representation of the (a) effect of crude extract of Alpinia nigra $(0.5$ and $1 \mathrm{mg} / \mathrm{ml})$ and praziquantel $(25$ and $50 \mu \mathrm{M})$ on Alkaline phosphatase activity with increasing pNPP (substrate) concentrations and (b) Lineweaver-Burk plot showing specific activities of alkaline phosphatase in the treated Fasciolopsis buski tissue.

$2.0 \mathrm{mM}$ and $11.36 \mathrm{U}$ for $1.0 \mathrm{mg} \mathrm{ml}^{-1}$ dose concentrations (Figure 1c). However, very little changes have been observed in y-intercept in PZQ treated tissue indicating competitive type of inhibition (Figure $\mathbf{4 b}$ ).

A large number of drugs/chemicals have been seen to alter activities of AlkPase. According to Mahanty et al., [24], AlkPase secreation in the culture medium have been found to reduced when the Taenia solium Cysts was treated with PZQ and albendazole. Martins et al., [25] studied the effects of different drugs like levamisole, theophylline, quinidine, kaempferol, genistein, lidocaine and 3-isobutyl1-methylxanthine on the activity of AlkPase and showed significant inhibitory effects by all the drugs on the enzyme activity. In a similar kind of experiment Parshad and Guraya [22] showed reduced activity of the enzyme in different helminth parasites treated with chemicals like $\mathrm{MgSO}_{4^{\prime}} \mathrm{CuSO}_{4^{\prime}}$ $\mathrm{FeCl}_{3}, \mathrm{KCN}, \mathrm{NaF}$, sodium citrate, glycine and formaldehyde. Similarly, variable degrees of inhibition of the AlkPase activities were achieved following the addition of the anthelmintics like Bilevon, Mansonil, Vermex, Zanil, Distodin and Carbon tetrachloride. Like helminth parasites, AlkPase of rat heart has also been found to be strongly inhibited by levamisole, theophylline and aspirin [26].

A large number of plant-products/extracts have also been exploited in different parts of the world to see their anthelmintic properties. In vitro and in vivo studies of many medicinal plants like Flemingia vestita and its active component, genistein, Alpinia nigra, Potentilla fulgens, Acacia oxyphylla, Butea monosperma, Embelia ribes, Roltleria tinctoria etc. have been found to cause changes in both alkaline and acid phosphatase activities in helminths like R. echinobothrida and F. buski $[12,13,27-30]$.

Isatin, an indole derivative showed competitive type of AlkPase inhibition when the purified enzyme extract of Echinococcus multilocularis metacestodes was treated with it [31]. In a similar kind of experiment, Audin et al., [32] showed a promising inhibitory efficacy of acetylcarboxanilide and 2-methacrylanilides against $E$. multilocularis metacestodes in vitro. In vitro treatment of the cestode parasite Raillietina echinobothrida by Albendazole and crude extract of Acacia oxyphylla showed $40 \%-48 \%$ reduction in AlkPase activity [28]. Similarly, in our earlier studies, reduction in the alkaline phosphatase activity has been noticed when the fluke $F$. buski exposed to alcoholic extracts of different traditionally 
used medicinal plants like Alpinia nigra, Potentilla fulgens and commercial drug praziquantel [12].

\section{Conclusion}

Plants parts or extract have been used since time immemorial to control helminth infections and are still in use as herbal remedies, particularly in developing countries. However, information on the mode of action of plantproducts is scant. In the present investigation we evaluated the activities of alkaline phosphatase, a vital tegumental enzyme of soft-bodied helminth parasite Fasciolopsis buski, under control and various stress conditions like, $\mathrm{pH}$, temperature, plant extract (Alpinia nigra) and drug (praziquantel). The altered enzyme activities, as observed under influence of the plant extract clearly indicate that the active principle of the plant acts as anthelminthic. However, to exploit the plant for commercial purpose, it is prerequisite to isolate and identify the active component responsible for anthelmintic activity.

\section{Competing interests}

The authors declare that they have no competing interests.

Acknowledgement

This study was supported by the Rajiv Gandhi National Fellowship to AS. Infrastructural support from DSA (UGC-SAP) programme to the Department of Zoology, and UPE-Biosciences programme to the School of Life Sciences, NEHU is gratefully acknowledged.

Publication history

Received: 18-Dec-2012 Revised: 21-Jan-2013

Re-Revised: 23-Jan-2013 Accepted: 24-Jan-2013

Published: 29-Jan-2013

\section{References}

1. Fried B, LeFlore WB and Bass HS: Histochemical localization of alkaline phosphatase activity in Leucochloridiomorpha constantiae (Trematoda) cultivated on the chick chorioallantois. The Journal of Parasitology 1985, 4:510-512. | Article | PubMed

2. Smyth JD: Introduction to Animal Parasitology. ( $3^{\text {rd }}$ Edition), Cambridge University Press, 1995.

3. Kwak KH and Kim $\mathrm{CH}$ : Characteristics of alkaline and acid phosphatase in Spirometra erinacei. Korean Journal Parasitology 1996, 34:69-77. | Article | PubMed

4. Marr J, Nilsen TW and Komuniecki RW: Molecular Medical Parasitology. (1 ${ }^{\text {st }}$ Edition), Academic Press, UK, 2002.

5. Kar PK and Tandon V: Anthelmintic efficacy of genistein, the active principle of Flemingia vestita (Fabaceae): Alterations in the activity of the enzymes associated with the tegumental and gastrodermal interfaces of the trematode, Fasciolopsis buski. Journal of Parasitic Diseases 2004, 28:45-56. I PDF

6. Roy TK: Histochemical studies on Raillietina (Rail-lietina) johri (Cestoda: Davaineidae). I. Nonspecific and specific phosphatases. Journal of Helminthology 1982, 53:45-49. | Article | PubMed

7. Poljakova-Krustena O, Mizinska-Boevska Y, Stojt-sova S: A cytochemical study of some phosphatases in the tegument of two cestode species. Helminthologia 1983, 16:64-67. I Article

8. Cesari IM, Simpson AJG and Evans WH: Properties of a series of tegumental membrane-bound phosphohydrolase activities of Schistosoma mansoni. Biochemical Journal 1991, 198:467-473. Article I PubMed Abstract | PubMed Full Text
9. Pappas PW: Activation and inhibition of the brush border membrane bound alkaline phosphatase activity of Hymenolepis diminuta Cestoda. Parasitology 1991, 10:141-146. | Article | PubMed

10. Gorchilova L, Polyakova-Krusteva O, Spaldonova R and Vinarova $M$ : Structural and functional characteristics of the tegument and intestinal wall in mature Fasciola hepatica after treatment with luxabendazole. Helminthologia 1990, 27:79-90. I Article

11. Pal $P$ and Tandon V: Anthelmintic efficacy of Flemingia vestita Leguminoceae: Genistein-induced alterations in the activity of tegumental enzymes in the cestode, Raillietina echinobothrida. Parasitology International 1998, 47:233-243. I Article

12. Roy B, Swargiary A and Giri BR: Alpinia nigra (Family Zingiberaceae): An anthelmintic medicinal plant of North-East India. Advances in Life Sciences 2012, 2:39-51. | Article

13. Roy B and Swargiary A: Anthelmintic efficacy of ethanolic shoot extract of Alpinia nigra on tegumental enzymes of Fasciolopsis buski, a giant intestinal parasite. Journal of Parasitic Diseases 2009, 33:48-53. | Article | PubMed Abstract | PubMed Full Text

14. Plummer DT: An introduction to Practical Biochemistry. (Third Edition), Tata McGraw-Hill Publishing Comp Ltd., New Delhi; 1988.

15. Njoku VO, Chikezie PC and Kaoje AM: Kinetic studies of alkaline phosphatase extracted from rabbit (Lepus townsendii) liver. African Journal of Biotechnology 2011, 10:3157-3162. I Article

16. Kamal MA, Greig NH, Alhomida AS and Al-Jafari AA: Kinetics of human acetylcholinesterase inhibition by the novel experimental Alzheimer therapeutic agent, Tolserine. Biochemical Pharmacology 2000, 60:561-570. | Article | PubMed

17. Alhomida AS, Al-Rajhi AA, Kamal MA and Al-Jafari AA: Kinetic analysis of the toxicological effect of tacrine (Cognex $\left.{ }^{\circledR}\right)$ on human retinal acetylcholinesterase activity. Toxicology 2000, 147:33-39. | Article | PubMed

18. Lowry OH, Rosebrough NJ, Farr AL and Randall RJ: Protein measurement with the folin phenol reagent. J Biol Chem 1951, 193:265-275. | Article | PubMed

19. Lawton P, Sarciron E and Petavy AF: Purification and characterization of the alkaline phosphatase from Echinococcus granulosus cyst membranes. The Journal of Parasitology 1994, 80:667-673. | Article | PubMed

20. Mazorra MT, Rubio JA and Blasco J: Acid and alkaline phosphatase activities in the clam Scrobicularia plana: kinetic characteristics and effects of heavy metals. Comparative Biochemistry and Physiology Part B 2002, 131:241-249. | Article | PubMed

21. Cox MM and Nelson DL: Lehninger Principles of Biochemistry $\left(5^{\text {th }}\right.$ Edn.), Macmillan, India; 2008.

22. Parshad VR and Guraya SS: Phosphatases in helminths: Effects of pH and various chemicals and anthelmintics on the enzyme activities. Veterinary Parasitology 1978, 4:111-120. I Article

23. Morales L, Gutiérrez N, Maya V, Parra C, Martínez-Barajas E and Coello $\mathrm{P}$ : Purification and characterization of an alkaline phosphatase induced by phosphorus starvation in common bean (Phaseolus vulgaris L.) roots. Journal of the Mexican Chemical Society 2012, 56:80-84. I PDF

24. Mahanty S, Paredes A, Marzal M, Gonzalez E, Rodriguez S, Dorny P, Guerra-Giraldez C, Garcia HH and Nash T: Sensitive in vitro system to assess morphological and biochemical effects of praziquantel and albendazole on Taenia solium cysts. Antimicrobial Agents and Chemotherapy 2011, 55:211-217. | Article | PubMed Abstract | PubMed Full Text

25. Martins MJ, Negrao MR and Hipolito-Reis C: Alkaline phosphatase from rat liver and kidney is differentially modulated. Clinical Biochemistry 2001, 34:463-468. | Article | PubMed

26. Mota A, Silva P, Neves D, Lemos C, Calhau C, Torres D, Martel $F$, Fraga $H$, Ribeiro L, Alçada MNMP, Pinho MJ, Negrao MR, Pedrosa R, Guerreiro S, Guimarães JT, Azevedo I and Martins MJ: Characterization of rat heart alkaline phosphatase isoenzymes and modulation of activity. Brazilian Journal of Medical and Biological Research 2008, 41:600-609. | Article | PubMed 
27. Tandon $V$ and Das B: In vitro testing of anthelmintic efficacy of Flemingia vestita (Fabaceae) on carbohydrate metabolism in Rallietina echinobothrida. Methods 2007, 42:330-338. | Article | PubMed

28. Lalchhandama K, Roy B and Dutta BK: In vitro anthelmintic activity of Acacia oxyphylla: Changes in the levels of trace elements and activities of the tegumental enzymes of the cestodes, Raillietina echinobothrida. Pharmacologyonline 2007, 2:307-317. | PDF

29. Lalchhandama K, Roy B and Dutta BK: Effects of Millettia pachycarpa on the trace metals and tegumental enzymes of Raillietina echinobothrida. Pharmacognosy Magazine 2008, 4:254-261. | Article

30. Roy B, Swargiary A, Syiem D and Tandon V: Potentilla fulgens (Family Rosaceae), a medicinal plant of North-east India: a natural anthelmintic. Journal of Parasitic Diseases 2010, 34:83-88. | Article | PubMed Abstract | PubMed Full Text

31. Sarciron ME, Hamoud W, Azzar G and Petavy AF: Alkaline phosphatase from Echinococcus multilocularis: purification and characterization. Comparative Biochemistry and Physiology Part $B$ 1991, 100:253-258. | Article | PubMed

32. Audin $P$, Sarciron $M E$, Paris J and Petavy $A F$ : In vivo and in vitro effects of methacrylanilides and acetylcarboxanilide on alkaline phosphatase activity of Echinococcus multilocularis metacestodes. European Journal of Medicinal Chemistry 1992, 27:285-289. | Article

\section{Citation:}

Swargiary A, Roy B and Ronghang B: Partial characterisation of alkaline phosphatase in Fasciolopsis buski - an intestinal fluke treated with crude extract of Alpinia nigra (Zingiberaceae). journal of Pharmaceutical Technology and Drug Research 2013, 2:5.

http://dx.doi.org/10.7243/2050-120X-2-5 